\title{
Convergences between the Brazilian National Health Plan and scientific articles on Neglected Tropical Diseases
}

\author{
Convergências entre o Plano Nacional de Saúde do Brasil e os Artigos \\ Científicos em Doenças Tropicais Negligenciadas
}

\section{Convergencias entre el Plan Nacional de Salud de Brasil y Artículos Científicos sobre Enfermedades Tropicales Desatendidas}

\author{
Natanael Vitor Sobral ${ }^{, a}$ \\ natanvsobral@gmail.com | http://orcid.org/oooo-0003-2410-494X \\ Viviane Martha Santos de Morais $^{2, b}$ \\ vivi.martha@hotmail.com | http://orcid.org/oooo-0001-7359-0820 \\ Leilah Santiago Bufrem ${ }^{3, c}$ \\ santiagobufrem@gmail.com | http://orcid.org/0000-0002-3620-0632 \\ Raimundo Nonato Macedo dos Santos ${ }^{3, d}$ \\ rnmacedo@uol.com.br | http://orcid.org/oooo-0002-9208-3266 \\ Fabio Mascarenhas e Silva ${ }^{3, e}$ \\ fabiomascarenhas@gmail.com | http://orcid.org/o000-0001-5566-5120
}

\footnotetext{
${ }^{1}$ Universidade Federal da Bahia, Instituto de Ciência da Informação. Salvador, BA, Brasil.

2 Universidade Federal Rural de Pernambuco, Unidade Acadêmica de Serra Talhada. Serra Talhada, PE, Brasil.

${ }^{3}$ Universidade Federal de Pernambuco. Programa de Pós-Graduação em Ciência da Informação. Recife, PE, Brasil.

a Doutorado em Ciência da Informação pela Universidade Federal da Bahia.

b Doutorado em Medicina Tropical pela Universidade Federal de Pernambuco.

c Doutorado em Ciências da Comunicação pela Universidade de São Paulo.

d Doutorado em Information Stratégique Et Critique Veille Technol. pela Université Paul Cézanne Aix Marseille III.

e Doutorado em Ciência da Informação pela Universidade de São Paulo.
}

\begin{abstract}
In Brazil, the National Health Plan (NHP) was the central instrument for public health planning from 2016 to 2019. In this paper, we show that there is a convergence between the Plan and the publication of scientific articles written by institutional researchers in the context of Neglected Tropical Diseases. The methodology used consisted of the following stages: identification of the universe of researchers, data collection, thematic characterization of Neglected Tropical Diseases in the Plan, organization of information, and production of indicators. In total, there were 2,719 researchers and 18,023 journal articles from 2015 to 2018. Of these, 2,541 articles, or 14.09\%, were related to Neglected Tropical Diseases. Regarding the convergences, there was strong alignment with leishmaniasis, Chagas disease, dengue, leprosy, schistosomiasis, and Chikungunya fever. However, the coverage of topics by scientific publications was broader than that of the political instrument due to the inclusion of other themes: snake bites, helminthiasis and lymphatic filariasis.
\end{abstract}

Keywords: Neglected diseases; Tropical Medicine; Scientific Publication Indicators; National health policy; Health research evaluation. 


\section{RESUMO}

O Plano Nacional de Saúde foi o instrumento central do planejamento em saúde pública de 2016 a 2019 no Brasil. Neste artigo, verificam-se as convergências entre o Plano e a produção de artigos científicos elaborada por pesquisadores institucionais no âmbito das Doenças Tropicais Negligenciadas. Os métodos estão divididos nas etapas de identificação do universo de pesquisadores, coleta de dados, caracterização temática das Doenças Tropicais Negligenciadas no Plano, organização das informações e produção de indicadores. No total, foram identificados 2.719 pesquisadores, que produziram 18.023 artigos de periódicos no período de 2015 a 2018. Desse cálculo, 2.541 artigos, 14,09\%, foram relacionados às Doenças Tropicais Negligenciadas. Em relação às convergências, há um grande alinhamento em leishmaniose, doença de Chagas, dengue, hanseníase, esquistossomose e febre de Chikungunya. No entanto, a produção científica apresenta cobertura superior ao instrumento político devido à contemplação de outros temas: picadas de cobra, helmintíase e filariose linfática.

Palavras-chave: Doenças Negligenciadas; Medicina Tropical; Indicadores de Produção Científica; Plano Nacional de Saúde; Avaliação da Pesquisa em Saúde.

\section{RESUMEN}

El Plan Nacional de Salud fue el instrumento central de la planificación de la salud pública de 2016 a 2019 en Brasil. En este artículo, existe una convergencia entre el Plan y la producción de artículos científicos elaborados por investigadores institucionales en el contexto de las Enfermedades Tropicales Desatendidas. Los métodos se dividen en las etapas de identificación del universo de investigadores, recolección de datos, caracterización temática de Enfermedades Tropicales Desatendidas en el Plan, organización de la información y producción de indicadores. En total, se identificaron 2.719 investigadores, quienes produjeron 18.023 artículos de revistas entre 2015 y 2018. De este cálculo, 2.541 artículos, 14.09\%, estaban relacionados con Enfermedades Tropicales Desatendidas. En cuanto a las convergencias, existe un gran alineamiento en leishmaniasis, enfermedad de Chagas, dengue, lepra, esquistosomiasis y fiebre chikungunya. Sin embargo, la producción científica tiene mayor cobertura que el instrumento político debido a la contemplación de otros temas: mordeduras de serpientes, helmintiasis y filariasis linfática.

Palabras clabe: Enfermedades desatendidas; Medicina tropical; Indicadores de Producción Científica; Política de salud; Evaluación de la investigación en salud.

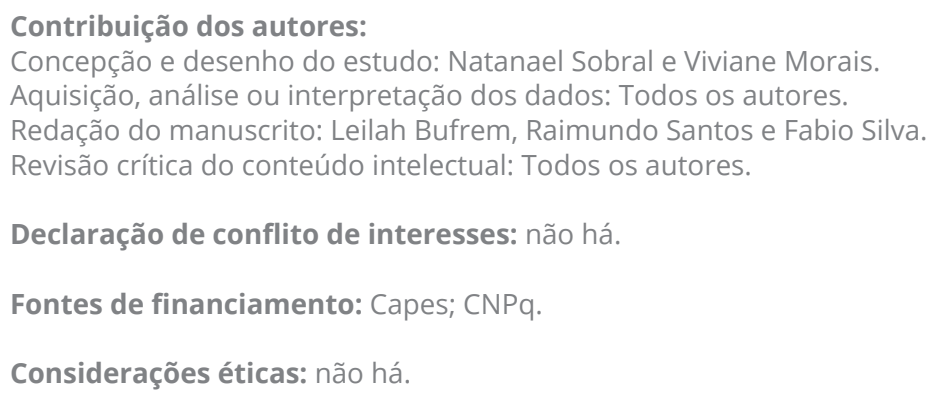

Licença CC BY-NC atribuição não comercial. Com essa licença é permitido acessar, baixar (download), copiar, imprimir, compartilhar, reutilizar e distribuir os artigos, desde que para uso não comercial e com a citação da fonte, conferindo os devidos créditos de autoria e menção à Reciis. Nesses casos, nenhuma permissão é necessária por parte dos autores ou dos editores. 


\section{INTRODUCTION}

In 2015, the World Health Organization (WHO) published an article entitled 'Accelerating progress on HIV, tuberculosis, malaria, hepatitis and neglected tropical diseases' (WHO, 2015a), proposing to end epidemics of Acquired Immunodeficiency Syndrome (AIDS), tuberculosis, malaria, and Neglected Tropical Diseases (NTDs) by 2030.

NTDs refer to a diverse group of transmissible diseases that are predominant in tropical and subtropical climates in 149 countries and affect more than a billion people. The populations that are most affected include those living in poverty, without adequate sanitation, and in close contact with infectious vectors including domestic animals and livestock (WHO, 2016). In the Americas, more than 33,00o new leprosy cases and more than 51,000 cases of cutaneous leishmaniasis are reported each year (OPAS, 2017). In addition, 70 million people in the region are at risk of contracting Chagas disease, 25 million suffer from schistosomiasis, and 12.6 million suffer from lymphatic filariasis (OPAS, 2017).

In general, the decrease in NTDs in the world is intrinsically associated with interdisciplinary actions. According to WHO, the involvement of complementary disciplines and professionals is essential, both for prevention and treatment, as well as curing these illnesses. Thus, the role of Information Science is considered an area of scientific knowledge historically dedicated to the production, selection, organization, interpretation, storage, recovery, dissemination, transformation, and use of information (GRIFFITH, 1980). Thus, in the context of the research on which this article is based, our focus is exploring and preparing the resources needed for the production and analysis of scientific information, reflecting on two specific contexts. One deals with the production of scientific knowledge, and the other is related to public policies, which can be narrowed, aligned, and mediated based on theories and methods posited on informational metrics.

In addition, another factor that is considered important for the sustainable resolution of problems related to NTDs is investment in Science, Technology, and Innovation (ST\&I), with an emphasis on the development of solutions suited to regional needs. According to WHO, a positive relationship was found between investments in Research, Development, and Innovation (RDI), and the production of medicines, vaccines, and diagnostic instruments related to NTDs. This highlights the importance of a scientific research schedule (WHO, 2015b). Thus, resources should be allocated to monitor the production of scientific knowledge on tropical health, which will make it possible to assess the convergence between science and political instruments.

In Brazil, as a central planning tool for public health actions, the Brazilian National Health Plan (NHP), in its latest version (2016 to 2019), provided guidelines for implementation of all management initiatives in the Unified Health System (Sistema Único de Saúde, or SUS). The guidelines explain the sectoral government commitments and reflect upon the health needs of the population (BRAZIL, 2016).

It should be noted that the NHP is not exactly a scientific policy. However, it is the main institutional document that describes the health conditions of the Brazilian population, including their needs regarding access to public health products and services, accompanied by planning. In this policy, goals were developed in order to meet the social health needs of Brazil, which include: expanding access to health services, improving health care networks, promoting comprehensive health care, reducing and preventing risks to the health of the population, increasing access to medicines, strengthening the production and dissemination of scientific and technological knowledge, improving health surveillance, enhancing supplementary health regulations, providing incentives for training health professionals, reinforcing transparency and citizen participation, improving the relationship between the states (and federal district) and the Federal Government, which manages SUS, and promoting in the distribution of resources, among other objectives. 
In this context, since the NHP is the key document that guided Brazilian public health planning in the period between 2016 to 2019, this article sought to determine the thematic convergence between the NHP and the publication of scientific articles by institutional researchers within the scope of NTDs. We compared the topics studied by the researchers to the subjects identified in the NHP, relating the efforts of the scientists to those of the government.

\section{METHODS}

The methodological procedures were organized as described in the five steps below.

Step 1) Identification of the universe of researchers: To map scientific articles, researchers were intentionally selected, based on the performance criteria of institutions with activities related to NTDs, establishing three representative groups: Research Graduate Programs, National Institutes of Science and Technology (NISTs), and employees of the Oswaldo Cruz Foundation (Fiocruz). From these groups, intentional and representative samples were constituted that could satisfy the purpose of the study and guarantee its feasibility. The first group selected involves researchers from RGPs (master's and doctoral degrees), considered the driving force of national science.

\section{Box 1 - Research Graduate Programs considered in the research universe}

\begin{tabular}{|c|c|c|}
\hline Research Graduate Programs & Institution & $\begin{array}{l}\text { Number of } \\
\text { Professors } \\
\end{array}$ \\
\hline Health Sciences in the Western Amazon & Universidade Federal do Acre & 23 \\
\hline Infectious Diseases & Universidade Federal do Espírito Santo & 19 \\
\hline $\begin{array}{l}\text { Infectious and Parasitic Diseases (Professional } \\
\text { Master's Degree) }\end{array}$ & Universidade de São Paulo & 10 \\
\hline Infectious and Parasitic Diseases & Universidade de São Paulo & 23 \\
\hline Medicine (Infectious and Parasitic Diseases) & Universidade Federal do Rio de Janeiro & 20 \\
\hline Infectious and Parasitic Diseases & Universidade Federal de Mato Grosso do Sul & 20 \\
\hline Tropical Diseases & Universidade Federal do Pará & 20 \\
\hline Tropical Diseases & $\begin{array}{l}\text { Universidade Estadual Paulista "Júlio de Mesquita } \\
\text { Filho" - Campus de Botucatu }\end{array}$ & 22 \\
\hline Clinical Research & Fundação Oswaldo Cruz & 48 \\
\hline Tropical Medicine & Fundação Oswaldo Cruz & 57 \\
\hline Infections, HIV, AIDS and Viral Hepatitis & Universidade Federal do Estado do Rio de Janeiro & 45 \\
\hline Infectious Diseases & Universidade Federal de São Paulo & 18 \\
\hline Infectious Diseases and Tropical Medicine & Universidade Federal de Minas Gerais & 25 \\
\hline Tropical Medicine & Universidade Federal de Pernambuco & 15 \\
\hline Tropical Medicine & Universidade do Estado do Amazonas & 34 \\
\hline Tropical Medicine and Public Health & Universidade Federal de Goiás & 32 \\
\hline Tropical Medicine & Universidade de São Paulo & 30 \\
\hline Tropical Medicine & Universidade de Brasília & 25 \\
\hline Tropical Medicine and Infectious Diseases & Universidade Federal do Triângulo Mineiro & 21 \\
\hline Health care in the Amazon & Universidade Federal do Pará & 24 \\
\hline Virology & Universidade Federal do Pará & 24 \\
\hline
\end{tabular}

Source: prepared by the authors. 
Researchers from Fiocruz's technical-scientific units were included in the category of research institutions in Science and Technology (S\&T) studying NTDs. More than a thousand research and technological development projects producing information on disease control (including AIDS, malaria, Chagas disease, tuberculosis, leprosy, measles, rubella, schistosomiasis, meningitis, and hepatitis) and other issues related to public health (such as violence, climate change, and the history of science) were screened (FIOCRUZ, c2019).

The list of employees of the institution was obtained through open data from the Federal Government's Transparency Portal [public servants] (BRASIL, c2020), obtained through the project "e-Lattes: a new framework in R language for analysing the Lattes curriculum". The spreadsheet obtained was based on the Transparency Portal and the Lattes Platform of the Conselho Nacional de Desenvolvimento Científico e Tecnológico (CNPq). Due to the large number of individuals, only researchers with a doctorate were selected, given that the main assumptions when forming the universe are involvement and active participation in scientific research. In total, 1,870 researchers were selected.

Finally, researchers linked to the NIST Program were selected. These institutes are formed by the best research groups in strategic areas for the development of Brazil (CNPQ, 2014). For selection of NISTs relevant to the universe of this study, the program's website was accessed by consulting the 'Institutes' tab and selecting the 'Health' category. This only identified, on the website, NISTs who claim to work with neglected, infectious, parasitic or tropical diseases, having some of these pathologies as their focus of research. As a result, 12 institutes (Box 2) were incorporated into the universe with their 403 researchers.

\section{Box 2 - National Institutes of Science and Technology encompassed in the research universe}

\begin{tabular}{|l|l|}
\hline NISTs & $\begin{array}{l}\text { Number of } \\
\text { Researchers }\end{array}$ \\
\hline CIBFAR - Center for Research and Innovation in Biodiversity and Pharmaceuticals & 22 \\
\hline $\begin{array}{l}\text { INCT-IDN - National Institute of Science and Technology for the Management of Innovation in } \\
\text { Neglected Diseases }\end{array}$ & 60 \\
\hline $\begin{array}{l}\text { INBEQMeDI - National Institute of Science and Technology for Structural Biotechnology and } \\
\text { Medicinal Chemistry in Infectious Diseases }\end{array}$ & 19 \\
\hline INOFAR - National Institute of Science and Technology of Drugs and Medicines & 38 \\
\hline INCT-DT - National Institute of Science and Technology in Tropical Diseases & 16 \\
\hline $\begin{array}{l}\text { INCT-INPeTAm - National Institute of Science and Technology in Translational Research in Health } \\
\text { and Environment in the Amazon Region }\end{array}$ & 46 \\
\hline INCT-FHV - National Institute of Science and Technology for Viral Hemorrhagic Fevers & 25 \\
\hline INCT-em Dengue - National Institute of Science and Technology in Dengue & 28 \\
\hline INCT-INDI - National Institute of Science and Technology for Diagnosis in Public Health & 42 \\
\hline INCT-iii - National Institute of Science and Technology for Immunology Research & 33 \\
\hline INCT-TB - National Institute of Science and Technology in Tuberculosis & 35 \\
\hline INCT-V - National Institute of Science and Technology of Vaccines & 39 \\
\hline
\end{tabular}

Source: prepared by the authors.

When adjustments were made for individuals who worked in more than one of the institutions selected, there was a total of 2,719 researchers.

Step 2) Collection of data about the researchers: For the survey of the scientific publications of the researchers, the Lattes Platform of CNPq was used. This Federal Government system is a repository for the academic curricula vitae of Brazilian researchers, and is a national standard for the registration of scientific, academic and technological activities carried out in Brazil. The tool ScriptLattes (MENA-CHALCO; CÉSAR 
JUNIOR, 2009) was used for data extraction for the period from 2015 to 2018. This coincided with the year in which the NHP was prepared, in 2015, the year it began, 2016, and the last full year of its term, 2018. Hence, data collection was performed in 2019. In the extraction process, in addition to viewing the report in HyperText Markup Language (HTML), a set of files were obtained in the Research Information Systems (.ris) format and the Comma-separated values (CSV) format, and these were explored using text mining and social network analysis, respectively. For information retrieval, the IDs of the 2,719 researchers in the Lattes database was used so that the data of the desired individuals could be found. The selected bibliometric variables were the titles of the articles and the years in which they were published.

Step 3) Thematic characterization of NTDs in the NHP: This was intended to identify a set of NTDs considered critical in Brazil and therefore present in political planning. For this, the NHP was accessed in .pdf format, and then the names of the NTDs were searched for in the content of the Plan. The purpose was to gather information on the coverage of diseases of interest in the political instrument, NHP, in order to compare it with the NTDs present in the published articles.

Stage 4) Organization of Information: After extracting the records of the articles from the CNPq Lattes Platform mentioned in step 2, the keywords of the articles were obtained based on the titles of the publications. For this, the automated text mining technique "natural language processing" was used, fractioning the titles of the articles and converting them into keywords using Vantage Point bibliometric software. This action was necessary, since the Lattes Platform does not have the keywords for most of the articles registered there.

Subsequently, to standardize the words, the Descritores em Ciências da Saúde da Biblioteca Virtual em Saúde (DeCS/BVS) was used, a list consisting of synonyms and descriptors in Spanish, English, and Portuguese so that there was no dispersion, ensuring treatment of cases of synonyms. This tool is the most important health thesaurus for the Brazilian scientific community, similar to Medical Subject Headings (MeSH) for English-speaking countries.

Thus, the terminological treatment of issues related to language and keywords was settled. Disease names were regarded as thematic items of analysis, established according to the WHO website, namely: Buruli ulcer, Chagas disease, Dengue and Chikungunya, Dracunculiasis (guinea-worm disease), Echinococcosis, Foodborne trematodiases, and Human African trypanosomiasis (sleeping sickness). Additional themes were Leishmaniasis, Leprosy (Hansen's disease), Lymphatic filariasis, Mycetoma, chromoblastomycosis and other deep mycoses, Onchocerciasis (river blindness), Rabies, Scabies and other ectoparasites, Schistosomiasis, Soil-transmitted helminthiases, Snakebite envenoming, Taeniasis/Cysticercosis, Trachoma, and Yaws (Endemic treponematoses).

Finally, the terms were standardized according to the alternatives provided by the thesaurus.

Stage 5) Production of Indicators: Mathematical matrices and rankings were produced. This helped in the analysis of the extent to which the subjects of the scientific articles (published by the researchers of the selected institutes) matched the NTDs included in the NHP. A representation of the convergences is presented in a table, relating the variables 'NTDs', 'Total occurrence', and 'Occurrence per year'. The information is also presented in a Venn diagram, clarifying associations between 'NTDs in scientific articles and 'NTDs in the NHP'.

\section{RESULTS}

There were 18,023 journal articles from 2015 to 2018, distributed as follows: 4,380 in 2015, 4,404 in 2016, 4,668 in 2017 and 4,571 in 2018. The numbers were relatively stable, with a slight increasing

i Health Sciences Descriptors System of the Virtual Health Library. 
trend from the first to the last year. This evidence the focus of researchers regarding the communication of scientific knowledge in articles published in scientific journals. Of this general calculation, there were 2,541 (14.09\%) articles on specific themes (as per the list suggested by WHO) related to NTDs. However, considering that an article could address more than one disease, 2,719 records were obtained. This low percentage was due to the fact that researchers linked to institutions with an interface in NTDs did not necessarily develop the research on these diseases, since the set of research lines of these institutions were broad and diversified with regard to specialties in public health. Below, in Table 1, the number of published articles on NTDs included in the study is systematically presented by year.

Table 1 - "NTDs" vs "Years" in complete articles published in journals (2015 to 2018)

\begin{tabular}{|c|c|c|c|c|c|}
\hline \multirow{2}{*}{$\begin{array}{c}\text { Total } \\
\text { occurrences }\end{array}$} & \multirow[b]{2}{*}{ NTDs } & \multicolumn{4}{|c|}{ Occurrences by Year } \\
\hline & & 2015 & 2016 & 2017 & 2018 \\
\hline 987 & Leishmaniasis & 220 & 240 & 275 & 252 \\
\hline 596 & Chagas disease & 131 & 153 & 135 & 177 \\
\hline 319 & Dengue & 59 & 88 & 101 & 71 \\
\hline 253 & Leprosy & 62 & 48 & 81 & 62 \\
\hline 209 & Schistosomiasis & 50 & 58 & 51 & 50 \\
\hline 75 & Chikungunya & 6 & 12 & 26 & 31 \\
\hline 73 & Snake bites & 17 & 14 & 18 & 24 \\
\hline 56 & Helminthiasis & 9 & 15 & 20 & 12 \\
\hline 47 & Filariasis & 11 & 18 & 5 & 13 \\
\hline 26 & Trachoma & 5 & 9 & 5 & 7 \\
\hline 22 & Cysticercosis & 1 & 9 & 5 & 7 \\
\hline 15 & Rabies & 3 & 2 & 4 & 6 \\
\hline 12 & Teniasis & 0 & 7 & 2 & 3 \\
\hline 10 & Chromoblastomycosis & 1 & 1 & 5 & 3 \\
\hline 9 & Echinococcosis & 1 & 1 & 4 & 3 \\
\hline 3 & Fascioliasis & 0 & 0 & 1 & 2 \\
\hline 2 & Dracunculiasis & 0 & 2 & 0 & 0 \\
\hline 2 & Scabies & 0 & 1 & 0 & 1 \\
\hline 2 & Mycetoma & 1 & 0 & 1 & 0 \\
\hline 1 & Onchocerciasis & 0 & 0 & 1 & 0 \\
\hline
\end{tabular}

Source: prepared by the authors.

As described in Figure 1, the convergence between the NHP and the publication of journal articles was identified, and the matching textual queries were produced using the names of each NTD, respecting the items contained in the DeCS/BVS thesaurus. 


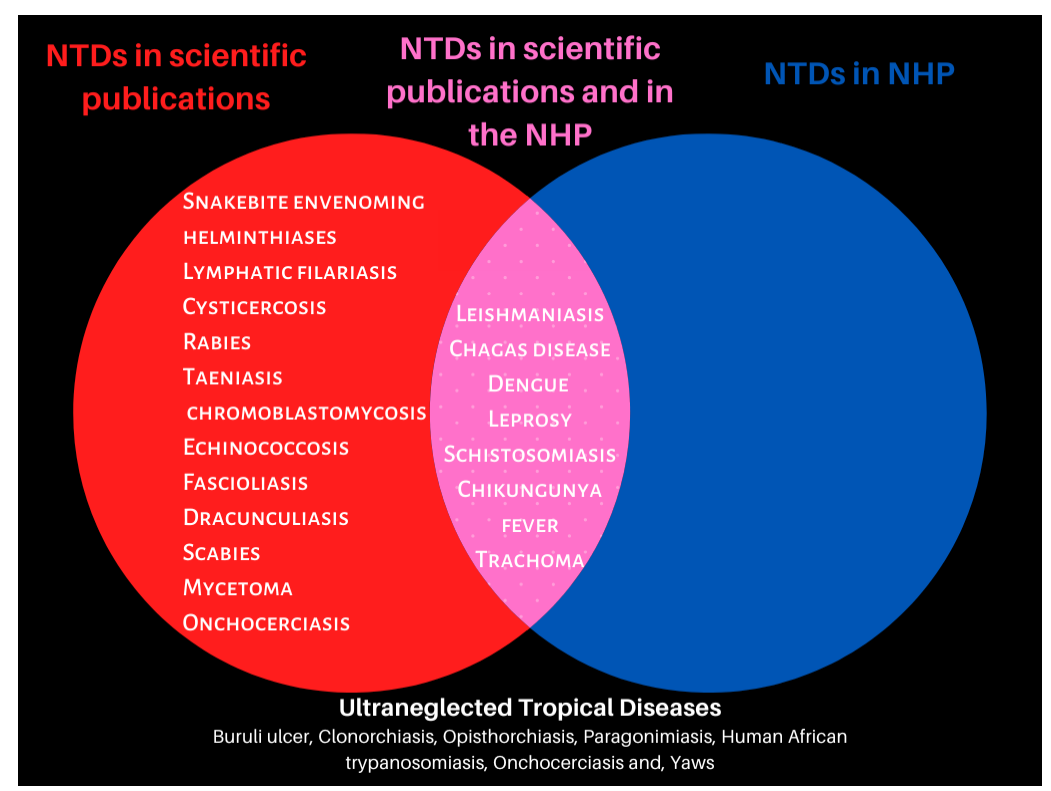

Figure 1 - Convergences between the themes related to NTDs in published articles (2015 to 2018) and the issues related to NTDs identified in the NHP Source: prepared by the authors.

\section{DISCUSSION}

In relation to table 1, these NTDs stand out: Leishmaniasis, Chagas disease, Dengue, Hansen's disease, and Schistosomiasis. Leishmaniasis is a group of diseases caused by more than 20 protozoan parasites of the Leishmania species. These parasites are transmitted to humans by the bite of an infected female sand fly, which is an insect vector. There are three main forms of leishmaniasis: cutaneous, visceral or kala-azar, and mucocutaneous. Most people infected with the parasite do not develop any symptoms in their lifetime. Therefore, the term leishmaniasis refers to the fact of being sick due to an infection by Leishmania and not to the simple fact of being infected with the parasite (WHO, c2021a).

On the other hand, Chagas disease, also known as American trypanosomiasis, is a potentially fatal disease caused by the protozoan parasite Trypanosoma cruzi. It is mostly found in 21 countries in Latin America, and is mainly transmitted by insect vectors. The major vector involved in the transmission of the parasite to humans is a triatomine, also known as the 'kissing bug'. In Brazil, it is popularly known as 'barber' and 'hickey'. It is estimated that 8 million people are infected worldwide, mainly in Latin America. Chagas disease is clinically curable if treatment is commenced at an early stage. Therefore, universal access to diagnosis and care is essential (WHO, c2O21b).

According to the description provided by WHO, dengue is a viral disease with the potential to cause pandemics in many parts of the world. Dengue occurs in poor urban areas, suburbs, and the countryside. However, it also affects wealthy neighbourhoods in tropical and subtropical countries. It is a viral infection transmitted by mosquitoes, and may develop into a potentially lethal complication called severe dengue, formerly known as haemorrhagic dengue. The incidence of dengue has increased by a factor of 30 over the past 50 years. It is estimated that up to 50-100 million infections occur annually in more than 100 endemic countries, endangering almost half of the world's population (WHO, c2021c). It is known that the eggs of the mosquito Aedes aegypti withstand dry environments, and when the summer rains arrive, contact with water allows the larva of the mosquito to hatch. In Brazil, the tropical climate favours breeding of the mosquito and, consequently, the spread of the virus (VALLE; AGUIAR; PIMENTA, 2015). 
Leprosy is a chronic infectious disease caused by Mycobacterium leprae, and mostly affects the skin, peripheral nerves, mucous surfaces of the upper respiratory tract, and the eyes. Leprosy is known to occur at all ages, from early childhood to old age. It is curable, and early treatment avoids most deficiencies (WHO, c2021d).

Schistosomiasis is a parasitic disease with an acute and chronic clinical picture. According to WHO, the infection is acquired when people are exposed to fresh water infested with the larval (cercariae) forms of parasitic bloodworms, known as Schistosoma. Schistosomiasis affects almost 240 million people worldwide, and more than 700 million people live in endemic areas. The infection is prevalent in tropical and subtropical areas, and in poor communities with inadequate drinking water and sanitation (WHO, c2021e).

In 2015, the total cost of Schistosomiasis mansoni in Brazil was an estimated US \$ 41.7 million dollars, with its greatest impact related to decreased productivity. The persistence of this disease in Brazil is a challenge not only for public health but also for several other sectors, especially the political class that has the means to influence the mobilization of public resources (NASCIMENTO; PEGADO; DOMINGUES; XIMENES et al., 2019).

Figure 1 shows a comparison between occurrences in the NHP and in the ranking of publications written by the researchers. Note that leishmaniasis, Chagas disease, dengue, leprosy, schistosomiasis, and Chikungunya fever are the six main diseases in terms of representativeness in scientific publication. They were mentioned in the Plan, indicating that these diseases were important public health problems in Brazil and are a concern in both academia and the political planning process.

Then, exploring the perverse phenomenon of negligence, ultra-neglected diseases are discussed within the scope of this study. These diseases are not the subject of articles produced in the universities considered and are not cited in the NHP. The following disease are being neglected by academia, the political sectors, and the government.

(a) Buruli ulcer is an infectious disease caused by Mycobacterium ulcerans and is one of the major NTDs (BOLEIRA; LUPI; LEHMAN; ASIEDU et al., 2010). After leprosy and tuberculosis, it is the third most common mycobacteriosis in terms of prevalence. It is a rare disease and few cases have been reported. The first Brazilian case was reported by dos Santos et al. (2007; BOLEIRA; LUPI; LEHMAN; ASIEDU et al., 2010).

(b) Clonorchiasis is a common infection of dogs and other fish-eating carnivores in China, North and South Korea, and Vietnam. Adult worms inhabit the bile ducts of a host and lay eggs, which are then are dispersed in the environment during defecation. When they reach fresh water, eggs develop into miracidia and are ingested by various species of aquatic snails (HUNG; MADSEN; FRIED, 2007). There are no indications of autochthonous cases of this parasitosis, nor are there any findings on the presence of this parasite in fish species caught or cultivated in Brazil (SANTOS, 2010).

(c) Opistorchiasis, which is used to identify two distinct infections: Opisthorchis viverrini, which is known as Opisthorchiasis viverrini, and Opisthorchis felineus, which is known as Opisthorchiasis felinea (WHO, c2021). Opisthorchiasis viverrini is a common infection of the musky cat and other mammals that eat fish, such as domestic cats and dogs (final hosts), in Cambodia, the Lao People's Democratic Republic, Thailand and Vietnam. Opisthorchiasis felinea is a common infection in cats, foxes, dogs, pigs, and other mammals that feed on fish (final hosts) in a wide geographic area that encompasses Eastern Europe, Central Asia and Siberia (WHO, c2021). So far, in Brazil, there are no confirmed autochthonous cases of the disease (MAGALHÃES; COSTA; TAVARES; CARVALHO, 2012).

(d) Paragonimiasis is an infection caused by a number of trematode species belonging to the genus Paragonimus. The most common include, P. westermani, P. heterotremus, and P. philippinensis in Asia (China, South Korea, North, Lao People's Democratic Republic, Philippines, Thailand, Vietnam, and other 
East Asian countries), P. africanus and P. uterobilateralis in West and Central Africa; and P. caliensis, $P$. kellicotti, and P. mexicanus in North, Central, and South America (WHO, c2021). Based on a clinical diagnosis compatible with this parasitosis and identification of parasite eggs in pulmonary sputum, a case of Paragonimiasis has been identified in Brazil (LEMOS; COELHO; MATOS; MONTAL et al., 2007).

(e) African trypanosomiasis: the Trypanosoma brucei hemoflagellate, the causative agent of human and animal African trypanosomiasis, is also known as sleeping sickness and nagana disease (STEVERDING, 2017). The infectious disease is transmitted by the bite of infected 'tsétsé' flies and mainly affects the rural populations of sub-Saharan Africa. The subspecies T. b. gambiense and T. b. Rhodesians are responsible for the two forms of human African trypanosomiasis in West and East Africa, respectively. A third subspecies, T. b. brucei, is only infectious for animals (STEVERDING, 2017).

(f) Onchocerciasis is a disease for which, according to WHO, more than $99 \%$ of infected people live in the 31 countries in Sub-Saharan Africa (WHO, c2021f). There have also been a few outbreaks of onchocerciasis in Latin America. Currently, of the 13 original outbreaks (WHO, c2021f), there are only two outbreaks in two countries, Brazil and the Bolivarian Republic of Venezuela.

(g) Bouba is a chronic skin infection caused by the bacterium Treponema pallidum, subspecies pertenue. Yaws mainly affects children under the age of 15 who live in poor communities in warm, humid, and tropical forest areas in Africa, Asia, Latin America, and the Pacific Islands (WHO, c2021g). The articles in the Brazilian scientific literature on this theme are from the 1940s, with important contributions from the protozoologist Felipe Nery Guimarães (1910-1975), of the Instituto Oswaldo Cruz (IOC).

From the analysis of the convergences, three important groups of diseases can be seen. The first contains the NTDs present in the articles published, but excluded from the NHP, including snake bites, helminthiasis, filariasis, cysticercosis, rabies, teniasis, chromoblastomycosis, echinococcosis, fascioliasis, dracunculiasis, scabies, mycetoma, and onchocerciasis. Thus, it appears that the coverage and capillarity of scientific publications are superior to those of political instruments. This suggests the need for communication between these sectors and a greater presence of scientists in the context of planning and political decision-making. In addition, there is a need to broaden the government's vision in relation to public health issues, especially within the scope of NTDs. The findings of this study will hopefully direct more attention and specific efforts towards the prevention and promotion of the health of the vulnerable populations.

The second group is the intersection between the NTDs present in scientific publications and included in the NHP, including, leishmaniasis, Chagas disease, dengue, leprosy, schistosomiasis, chikungunya fever, and trachoma. According to the data compiled from the Information System for Notifiable Diseases (SINAN), there were 23,412 confirmed cases of leishmaniasis in 2017; 380 confirmed cases of Chagas disease in 2018 (SINAN, 2017); 239,395 cases of probable dengue in 2017 (SINAN, 2017); a general detection coefficient for leprosy of 12.94 cases per 100,000 inhabitants, consequently making Brazil a highly endemic country (BRASIL, 2018; BOIGNY; SOUZA; ROMANHOLO; ARAÚJO et al., 2019); and 4,359 confirmed cases of schistosomiasis in 2017 (SINAN, 2017). Therefore, the alignment of political and scientific interests in this group of NTDs commonly occurring in Brazil is a positive factor.

The third group represents the NTDs that are considered ultra-neglected and, as seen above, have no significant presence in Brazil.

In addition to these, we recognized a fourth group of diseases outside the NHP and appearing in less than a dozen scientific articles, including, echinococcosis, fascioliasis, dracunculiasis, scabies, mycetoma, and onchocerciasis. Although these diseases are controlled or almost eradicated, attention should be paid to their occurrence, since relaxation of policies and research can contribute to future outbreaks and disturbances in the public health system in Brazil. We restate that an essential factor for a disease to be considered 
neglected is its neglect in health policies, scientific publications, and medicines. This also includes the low number of published studies, indicating the ultra-neglected character of this group.

\section{CONCLUSION}

We conclude by emphasizing the lack of interest of researchers in some diseases that do not directly affect Brazil, including African trypanosomiasis, opistorchiasis, clonorchiasis, Buruli ulcer, and dracunculiasis, among others. Concerning the convergences, there was high alignment between the main NTDs studied by the researchers and the NHP, which highlighted leishmaniasis, Chagas disease, dengue, leprosy, schistosomiasis, and Chikungunya fever.

Snake bite, helminthiasis, and lymphatic filariasis, among other diseases, were discussed only in scientific publications, demonstrating the greater capillarity and coverage capacity of the scientific segment. Thus, in order to add value to the plans prepared by the Federal Government, it is important to seek to involve scientists in political planning. The combination of the perceptions of these two groups of actors can be useful in the construction of a more realistic vision of the social needs of the population.

The lack of scientists in political planning decision-making is intentional, demonstrating the place of Science in the current political configuration of Brazil. The consequence of this is the successive cuts and restrictions in the budget destined to scientific research. This stance has resulted in a decrease in grants and resources for the development of projects, and it has hindered the launch of important specific programs for NTDs, such as those seen previously with the 'National Plan for Surveillance and Control of Enteroparasites' (2005), the 'Growth Acceleration Program' (PAC) (2007) that provided for basic sanitation actions with the goal of reducing infectious and parasitic diseases (FONSECA; TEIXEIRA; BARRETO; CARMO et al., 2010), and the 'Integrated plan for strategic actions to eliminate leprosy, filariasis, schistosomiasis and onchocerciasis as a public health problem, trachoma as a cause of blindness and control of geohelminthiasis', which aimed to reinforce the political and institutional commitment to reduce the burden of this group of diseases.

Regarding the limitations of the study, we recognize that there are other important institutions that could be incorporated into future research, such as the Instituto de Medicina Tropical (IMT) linked to the University of São Paulo; the Fundação de Medicina Tropical Doutor Heitor Vieira Dourado (FMT-HVD) and the Instituto Nacional de Pesquisas da Amazonia (INPA), both located in Amazonas; and the Institute of Tropical Medicine (IMT-RN) at the Federal University of Rio Grande do Norte. The constant expansion of this coverage will promote understanding of the current dynamics of scientific publication in the field and its reverberation in public policies.

\section{REFERENCES}

BOIGNY, Reagan Nzundu; SOUZA, Eliana Amorim de; ROMANHOLO, Helizandra Simoneti Bianchini; ARAÚJJ, Olivia Dias de et al. Persistência da hanseníase em redes de convívio domiciliar: sobreposição de casos e vulnerabilidade em regiões endêmicas no Brasil. Cadernos de Saúde Pública, Rio de Janeiro, 2019;35(2):e00105318. Available from: http://www.scielo.br/scielo.php?script=sci arttext\&pid=S0102311X2019000205012\&Ing=pt. Cited in: 2020 Abr 18.

BOLEIRA, Manuela; LUPI, Omar; LEHMAN, Linda; ASIEDU, Kingsley Bampoe et al. Úlcera de Buruli. Anais Brasileiros de Dermatologia, Rio de Janeiro, v. 85, n. 3, p. 281-301, 2010. Available from: http://www.scielo. br/scielo.php?script=sci_arttext\&pid=S0365-05962010000300002\&lng=en. Cited in: $2020 \mathrm{Apr} 18$.

BRASIL. Controladoria Geral da União. Servidores. In: BRASIL. Portal da Transparência. Brasília, DF: Controladoria Geral da União, c2020. Available from: http://www.portaltransparencia.gov.br/servidores. Cited in: 2021 Jun 12. 
BRASIL. Ministério da Saúde. Plano Nacional de Saúde: PNS 2016-2019. Brasília, DF: The Ministry, 2016. Available from: http://bvsms.saude.gov.br/bvs/publicacoes/plano nacional saude_2016_2019_30032015 final.pdf. Cited in: 2021 Jun 12.

BRASIL. Ministério da Saúde. Secretaria de Vigilância em Saúde. Indicadores epidemiológicos e operacionais de hanseníase: Brasil 2001-2017. [Brasília, DF: The Ministry, 2018]. Available from: https:// portalarquivos2.saude.gov.br/images/pdf/2018/julho/13/Indicadores-epidemiologicos-e-operacionais-dehanseniase-Brasil-2001-a-2017.pdf. Cited in: 2021 Jun 16.

CONSELHO NACIONAL DE DESENVOLVIMENTO CIENTÍFICO E TECNOLÓGICO (CNPq). INCTs. Brasília, DF: CNPq, 2014. Available from: http://inct.cnpq.br/. Cited in: 2020 Jan 5.

FONSECA, Eduardo Oyama Lins; TEIXEIRA, Maria Glória; BARRETO, Maurício Lima.; CARMO, Eduardo Hage et al. Prevalência e fatores associados às geo-helmintíases em crianças residentes em municípios com baixo IDH no Norte e Nordeste brasileiros. Cadernos de Saúde Pública, Rio de Janeiro, v. 26, n. 1, p. 143-152, 2010. Available from: http://www.scielo.br/scielo.php?script=sci_arttext\&pid=S0102$\underline{311 \times 2010000100015 \& l n g=e n}$. Cited in: $2021 \mathrm{Abr} 01$.

FUNDAÇÃO OSWALDO CRUZ (FIOCRUZ). Pesquisa e Ensino. Rio de Janeiro: Fiocruz, c2019. Available from: https://portal.fiocruz.br/pesquisa-e-ensino. Cited in: 2020 Mar 6.

GRIFFITH, Belver C. (ed.). Key papers in information science. New York: Praeger, 1980.

HUNG, Nguyen Manh; MADSEN, Henry; FRIED, Bernard. Global status of fish-borne zoonotic trematodiasis in humans. Acta Parasitologica, Warszawa, v. 58, n. 3, p. 231-258, 2013. DOI: https://doi.org/10.2478/s11686013-0155-5. Available from: https://pubmed.ncbi.nlm.nih.gov/23990419/. Cited in: 2021 Jun 15.

LEMOS, Antônio Carlos Moreira; COELHO, João Carlos; MATOS, Eliana Dias; MONTAL, Guilherme et al. Paragonimiasis: first case reported in Brazil. Brazilian Journal of Infectious Diseases, Salvador, v. 11, n. 1, p. 153-156, 2007. DOI: https://doi.org/10.1590/S1413-86702007000100031. Available from: http://www. scielo.br/scielo.php?script=sci arttext\&pid=S1413-86702007000100031\&lng=en. Cited in $2020 \mathrm{Apr} 18$.

MAGALHÃES, Ângela Muniz Souza; COSTA, Barbara Salgado; TAVARES, Guilherme Campos; CARVALHO, Sarah Indyla Guilherme. Zoonoses parasitárias associadas ao consumo de carne de peixe cru. Pubvet, Maringá, v. 6, n. 25, p. 1411-1416, 2012. Available from: https://www.pubvet.com.br/artigo/3274/zoonosesparasitaacuterias-associadas-ao-consumo-de-carne-de-peixe-cru. Cited in: 2021 Jun 15.

MENA-CHALCO, Jesús Pascual; CÉSAR JUNIOR, Roberto Marcondes. ScriptLattes: an opensource knowledge extraction system from the Lattes platform. Journal of the Brazilian Computer Society, São Paulo, v. 4, n. 1, p. 31-39, 2009. Available from: https://www.scielo.br/j/jbcos/al DNaND3wQHrTHkCNWQbKx6pt/?lang=en. Cited in 2021 Jun 12.

NASCIMENTO, Gilmara Lima; PEGADO, Helio Milani; DOMINGUES, Ana Lúcia Coutinho; XIMENES, Ricardo Alencar Arraes et al. The cost of a disease targeted for elimination in Brazil: the case of schistosomiasis mansoni. Memórias do Instituto Oswaldo Cruz, Rio de Janeiro, v. 114, p. e180347, 2019. DOI: https://doi.org/10.1590/0074-02760180347. Available from: https://www.scielo.br/j/mioc/a/ k5DcPJT75kPXbksyk8CVSHH/?lang=en. Cited in: 15 jun. 2021.

ORGANIZAÇÃO PAN AMERICANA DA SAÚDE (OPAS). Relatório da OMS informa progressos sem precedentes contra doenças tropicais negligenciadas. In: SIMEPAR. Blog Simepar, [s. I.], 2017 Apr 17. Available from: https://simepar.org.br/blog/relatorio-da-oms-informa-progressos-sem-precedentes-contradoencas-tropicais-negligenciadas/. Cited in 2021 Jun 12.

SANTOS, Carlos Alberto Muylaert Lima dos. Doenças transmitidas por pescado no Brasil. Brazilian Journal of Veterinary Medicine, Seropédica, v. 32, n. 4, p. 234-241, 2010. Available from: https://rbmv.org/BJVM/ article/view/857. Cited in: 2021 Jun 15.

SANTOS, Vitorino Modesto dos; NORONHA, Flávio Luiz Alves.; VICENTINA, Erica Carvalho.; LIMA, Camila do Carmo. Mycobacterium ulcerans infection in Brazil. The Medical Journal of Australia, Sydney, v. 187, n. 1, p. 63, 2007. DOI: https://doi.org/10.5694/j.1326-5377.2007.tb01138.x. Available from: https://pubmed.ncbi. nlm.nih.gov/17605722/. Cited in: 2021 Jun 15.

SISTEMA DE INFORMAÇÃO DE AGRAVOS DE NOTIFICAÇÃO (SINAN). Dados Epidemiológicos Sinan: Brasília, DF: Ministério da Saúde, 2017. Available from: http://portalsinan.saude.gov.br/dadosepidemiologicos-sinan. Cited in: 2020 Feb 10. 
STEVERDING, Dietmar. Sleeping Sickness and Nagana Disease Caused by Trypanosoma brucei. In: MARCONDES, Carlos Brisola (ed). Arthropod Borne Diseases. Switzerland: Springer, 2017. p. 277-297.

VALLE, Denise; AGUIAR, Raquel; PIMENTA, Denise. Lançando luz sobre a dengue. Ciência e Cultura, São Paulo, v. 67, n. 3, p. 4-5, 2015. Available from: http://cienciaecultura.bvs.br/scielo.php?script=sci_arttext\&pid $=$ S0009-67252015000300002. Cited in: 2021 Jun 15.

WORLD HEALTH ORGANIZATION (WHO). Accelerating progress on HIV, tuberculosis, malaria, hepatitis and neglected tropical diseases: a new agenda for 2016 - 2030. Geneva: WHO, 2015a. Available from: https://apps.who.int/iris/handle/10665/204419. Cited in: 2021 Jun 12.

WORLD HEALTH ORGANIZATION (WHO). Chagas disease (American trypanosomiasis). Geneva: WHO, c2021b. Available from: https://www.who.int/health-topics/chagas-disease\#tab=tab_1. Cited in: 2021 Jun 19.

WORLD HEALTH ORGANIZATION (WHO). Control of neglected tropical diseases. Geneva: WHO, 2016. Available from: https://www.who.int/teams/control-of-neglected-tropical-diseases. Cited in: 2020 Jan 10.

WORLD HEALTH ORGANIZATION (WHO). Foodborne trematode infections. Geneva: WHO, 2021. Available from: https://www.who.int/news-room/fact-sheets/detail/foodborne-trematode-infections. Cited in: 2021 Jun 19

WORLD HEALTH ORGANIZATION (WHO). Leishmaniasis. Geneva: WHO, c2021a. Available from: https:// www.who.int/health-topics/leishmaniasis\#tab=tab 1. Cited in: 2021 Jun 19.

WORLD HEALTH ORGANIZATION (WHO). Leprosy (Hansen's disease). Geneva: WHO, c2021d. Available from: https://www.who.int/health-topics/leprosy\#tab=tab_1. Cited in: 2021 Jun 19.

WORLD HEALTH ORGANIZATION (WHO). Onchocerciasis (river blindness). Geneva: WHO, c2021f. Available from: https://www.who.int/health-topics/onchocerciasis\#tab=tab_2. Cited in: 2021 Jun 19.

WORLD HEALTH ORGANIZATION (WHO). Promoting dengue vector surveillance and control. Geneva: WHO, c2021c. Available from: https://www.who.int/activities/promoting-dengue-vector-surveillance-andcontrol. Cited in: 2021 Mar 19.

WORLD HEALTH ORGANIZATION (WHO). Schistosomiasis (Bilharzia). Geneva: WHO, c2021e. Available from: https://www.who.int/health-topics/schistosomiasis\#tab=tab 1. Cited in: 2021 Mar 19.

WORLD HEALTH ORGANIZATION (WHO). The millennium development goals report. Geneva: WHO, $2015 b$.

WORLD HEALTH ORGANIZATION (WHO). Yaws (Endemic treponematoses). Geneva: WHO, c2021g. Available from: https://www.who.int/health-topics/yaws\#tab=tab_1. Cited in: 2021 Jun 19. 